\title{
REVITALIZATION AND SOCIALIZATION OF DAENG DANCE IN PURBALINGGA, INDONESIA
}

\author{
Dinar Anggraeni \\ ${ }^{\bowtie}$ A Practitioner of the Art, Stay in Purbalingga, Indonesia \\ E-mail: dinaranggraeni65@yahoo.com
}

Received: April 22, 2015. Revised: May 5, 2015. Accepted: June 13, 2015

\begin{abstract}
The purpose of the study is to know and depict the revitalization and socialization of Daeng dance in purbalingga, Indonesia. This study used a qualitative method. The relevant techniques of data collection to the method are observation, interview, and documentation. The data obtained are analyzedusing three ways; they are data reduction, data display, conclusion and verification. The results showed that revitalizing Daeng dance occurred in its earliest performances, by means of innovating the foregoing Daeng dance without leaving its characteristics. The revitalization was done toward the dance's motion, accompaniment, makeup, wardrobe, stage, sounds, lighting, and floor patterns, as well as there is a change in its function; as the media of spreading Islam in the past to nowadays just being an entertainment. After the process of revitalization, Daeng dance is then socialized through two ways of deployment; they are formal and informal processes. This dance's socialization in this study occurs through direct performance and mass media.
\end{abstract}

Keywords: Daeng Dance; Purbalingga; revitalization

How to Cite: Anggraeni, D. (2015). Revitalization and Socialization of Daeng Dance in Purbalingga, Indonesia. Harmonia: Journal of Arts Research And Education, 15(1), 56-61. doi:http://dx.doi.org/10.15294/harmonia.v15i1.3755

\section{INTRODUCTION}

Each area has an art performance, whose condition looks advance or less. According to Soedarsono (1998, p. 1), there are many things that cause the extinction of an art performance in an area. Sometimes, changes that occur in politics and an inability to compete with other forms of performance are the causes of the extinction. Similarly, the community is going to be interested in things that are more popular than traditional art performances, so it will require a change in the community's point of view.

If there is a change in one part, it will affect other parts that ultimately affect the overall social system's condition. A dance will always face changes from time to time. Sometimes, it is under the reason of less demand from the audience toward the dance since it is very monotonous either from the aspects of its performance or its parts of motion (Hadi, 2005, p. 37). Similarly, in the area of Purbalingga, there is an art that is abandoned since it is considered outdated and unable to compete with the new cultures. However, some institutions are still going to make many efforts to lift it, like Dinbudparpora (Department of Culture, Tourism, and Sports) which play a major role in revitalizing the art that became locally extinct so as to be presented again with a new style and artistry that can provide the interest of the community.

One of the revitalized dances is Daeng dance. It is one of the traditional dances that thrive in the Purbalingga. It is experiencing a process of revitalization in Senior High School 1Bobotsari. 
A revitalization is an effort to return once the essential so as to undergo degradation. It is oriented not only on solving the sheer physical beauty, but also for coming with the improvement of its community as well as the introduction of the existing cultures (Alfita, 2012).

Some arts revitalization have been much done by some institutions who are paying attention to that issue. Some forms of revitalizing the art as revealed by Supanggah (2008) include reconstruction, refunction, representation, reformation, reinterpretation, reorientation, and recreation.

The arts of dance, whose presence surely cannot be separated from the community supporters, comprise the dancesofprimitive culture, traditional dances that developed in castles, the dances among rural communities, growing urban dances, and modern dances (Hadi, 2005, p. 13). The presence of dance forms will appear in the design of motion, the pattern of motion continuity, and the supporting elements of the appearance of the dance, as well as its compliance with the intention and purpose of the dance (Jazuli, 1994, p. 4).

A motion is essential in a dance. It is a sign of life, the first and last human's reaction towards life, the situations, and the activities of others. The feelings of dissatisfaction, disappointment, love, fear, and hurt are always experienced through subtle changes of body movement. Living means moving and a motion is the raw material of dance (Murgiyanto, 1983, p. 20).

There is a close relation between music and dance. Both are derived from the same source; that is the urge or rhythmic human instincts. Music is a pair of dance, as it is not a mere accompaniment, but it is an inseparable part of the dance (Murgiyanto, 1983, p. 43).

Indonesia is known with some forms of venue, such as the open field or arena, pendapa (an open veranda), and staging. There are various forms of staging, or often referred to forms of performance. For example, the proscenium form in which the audience can only see from the front side only, the horseshoe shaped stage in which the audience can see from three sides, and the horseshoe form of pendapa (an open veranda) with its higher building than horseshoe shaped stage (Jazuli, 1994, p. 20).

There are three types of makeup, namely corrective makeup, fantasy dressing, and character dressing. A corrective makeup is the makeup for the purpose of repairing parts of the face that is not perfect, like repairing the shape of eyebrows, the shape of nose, and lips. A fantasy dressing is the makeup as a result imagination. A character's makeup is the makeup for the purpose of clarifying the character, or dance characters (Pekerti, 2008, p. 36).

Fashion is also very supportive in a dance. There is no need for a dance clothing to look glamorous and glitzy, but it should be able to provide unhampered motions of the dancers and also a great interest for the audience as well as it helps strengthen the expression of motion. In a traditional dance, a dance clothing often reflects the identity of an area that at once represents to the origin of the dance (Jazuli, 1994, p. 6).

A sound system is a set of sound instruments that has the purpose to set up the music and dance accompaniment. The sound instruments will help to clarify the voice or sound of music accompaniment; thus, the dance performance becomes more alive (Pekerti, 2008, p. 39).

A lighting is a set of lights on the stage. It is not only for the purpose of lighting in a show, but also serves to strengthen an atmosphere of dance. The lighting setup is not only for a mere lighting, but also serves to create a dramatic effect and gives vitality to a dance performance, either directly or indirectly (Jazuli, 1994, p. 25).

A floor pattern or design is floor stripestraversed by a dancer or by the formation of a group of dancers. There are two sorts of line; straight and curved lines (Murgiyanto in Sedyawati, 1986, p. 106).

The dances often have a function at each event in life, as revealed by Jazuli (1994, p. 43) that the functions of dance are for the purposes of ritual, entertainment, 
performance art, and education media.

A socialization according to the experts, such as Bruce J. Cohen, is the process which human beings learn how to live in the society, to gain the personality, and to establish the capacity to have functions, both as individuals and community members. According to David Gaslin, a socialization is one's process of learning to acquire knowledge of values and norms, so that he may participate as a member of a community (Damanik, 2010, p. 79).

Based on its type, the process of socialization that takes place within the community can be distinguished into two. The first is a formal socialization that occurs through the authorized institutions under the provisions in the state, such as formal education in the school. The second is an informal socialization that takes place in the community or in groups of friends or best friends (Damanik, 2010, p. 83).

\section{METHOD}

This research examines about revitalization and socialization of Daeng dance in Purbalingga; therefore, the appropriate research method for this kind of examination is a qualitative method. As Bogdan Taylor (as quoted by Moleong 2007, p. 4) defined a qualitative method also the research procedure that generatesdescriptive data about the observed behaviours. This means that the issues that will be discussed in this study does not deal with a numeral, but rather the description of an overview of the results which contains a discussion of the problems examined.

The problems discussed in this research aims to find out how the revitalization and socialization of Daeng dance in Purbalingga. The data collection techniques are observation, interview, and documentation.

The analysis of research data began with a data collection through the techniques of interview, observation, and documentation. The collected data are further processed before it is ready to use. The data analysis continues to use words that are compiled into the text, otherwise called descriptive data. The data analysis is divided into three stages; they are data reduction, data display, and conclusion. A source triangulation is used to get the data validity.

\section{RESULTS AND DISCUSSION}

The location of the research is in Purbalingga Regency. It is one of the regencies in Central Java, in the area of Banyumas district. Purbalingga is a place of socialization and development of Daeng dance, while its revitalization is in Senior High School 1 Bobotsari.

This high school is a favourite school in Purbalingga. It is located in Bobotsari sub-district, precisely in the area of Majapura. Senior High School 1 Bobotsari is a state high school approximately located 11 $\mathrm{km}$ to the north of Purbalingga. The location is not so far from the main street. The entire land area is approximately 27,806 $\mathrm{m} 2$ consisting of main buildings and courtyard about 12,499 $\mathrm{m} 2$ and a front yard $15,357 \mathrm{~m} 2$.

This school is a place to the onset of the process of revitalizing Daeng dance where the revitalization is occurring under the provision of Dinbudparpora (Department of Culture, Tourism, and Sports) to redevelop the dance who began to suffer extinction.

The results and discussion of the research focused on the revitalization and socialization of Daeng dance in Purbalingga, which contain a brief history of Dance, dance, the revitalization process, the shape of the show after revitalization and socialization.

\section{Revitalization Process of Daeng Dance}

The revitalization took place on October 13, 2013 toward the dance's motion, accompaniment, makeup, wardrobe, staging, sounds, lighting, and floor patterns.

The revitalization process occurs by means of innovating the foregoingtodevelop both in terms of motion, accompaniment, staging, wardrobe, makeup, 
lighting, sounds, and floor patterns. This development is intended to increase the acceptance toward Daeng dance.

\section{A Brief History of Daeng Dance}

Daeng dance is one of a variety of traditional arts and folk performance that live and thrive in Purbalingga.

This dance was once performed by men as there were silat movements that became the characteristics of the dance. There are steps to do, like initially the dancers line up, then they pit one by one, two by two, until at the end of the show, there are attractions, such as playing a machete, consuming beling (glass), and playing a whip.

This dance is usually performed by ten male dancers. Before the performance, there is usually a ritual from the leader of the arts group so as to have inner power in time of attractions when the dance is performed.

The Daeng dance continually started to remove and had lack attention anymore, though it was not totally disappeared, but the audience was rare when there was a performance. The audience was only the people around. Soon, no more people invited the group to perform anymore.

The dance is going to get the attention of government through Dinbudparpora (Department of Culture, Tourism, and Sports) by means of revitalizing the dance, innovating the form of dance performances, and performing it in senior high school 1 Bobotsari on October 13, 2013.

\section{Form of Daeng Dance Performances}

The form of Daengdance performance to explain here is the form after revitalization. The forms of the show include motion, accompaniment, stage, fashion, makeup, lighting, sounds, and floor pattern which have all undergone innovations.

\section{Motion}

Motion is the most essential element in the dance. The revitalization in motion is the innovation toward the foregoing dance motions, but it is not leaving its characteristics, such as silat movements.

The innovated dance motions are slightly easier so as to be easy to follow, though there are no longer attractions in this dance since the dancers are all female, but the characteristics of silat movement still exists. The development in dance motions is aimed to make it look much more interesting and can be easily accepted by the public.

\section{Accompaniment}

The accompaniment of the dance used the music instruments of Islam since it was used as the media to spread Islam. The accompaniment used six tambourines, akendang (a small drum covered with leather at each end), and abedug (large drum suspended horizontally at the mosque).

The dance is also accompanied by the song which the musicians sing. The song is sung at the beginning and the middle of the dance. It also adds the characteristics of the dance due to the strangeness of the song's lyric so as to make the dance more interesting.

\section{Staging}

There is no specific place or the stage to perform the dance. It can be staged on the closed stage, open stage, in a field, or on the streets.

\section{Wardrobe}

A wardrobe is a proponent in the dance presentation, as a good makeup will make the dancers' appearance look more attractive. The dancers use a corrective makeup that only thickens some parts of the face to make it look more beautiful. The hair is hung loosely and simply combed only.

\section{Clothing}

The dancers of Daeng dance wear along plain red sleeve shirt with gold studs in front of the chest and three-fourth red trousers with a silver lace on the tip of the pants. The dancers wear the accessories, like a golden colored irah-irahan adorned 
with red, green, blue, and orange mutes, a gold sumping is adorned with a length wise mute, a golden kace or nated with a golden lace and a golden flower, a pair of green bracelets with golden lace ornaments,long white socks,and the last,a pair of green anklet ornated with golden lace. The dancers also wear black-colored glasses.

Besides using some accessories, the dancers also use some propeties, like golden-colored sampur (a long scarf) tightened on the left and right side of the waist, a golden slepe (a belt), and a yellow golden rampek, The moccasins are only used to protect the dancers' feet from sharp objects when dancing in a field, in the lawn, and in the streets.

\section{Sounds}

A sound system is a set of sound instruments for organizing music sound as a dance accompaniment. The music players play live music, so they only need a microphone connected to an amplifier and forwarded to a speaker. It has a purpose for the dancers to be able to hear the accompaniment performed, if this dance is performed either in the closed room or in the open space.

\section{Lighting}

The dance can be performed during the day or night. Necessary lights are needed to support the dance performance at night, but it is not necessary to use lights during the day in the courtyard or on the street as the only light used is the sunlight. It is aimed to make the dance more noticeable by the audience.

\section{Floor Pattern}

Floor patterns are used to make the appearance more interesting. The use of floor patterns is also intended to make the performance, impressive, not monotonous as floor patterns give the impression to the audience, and it gives space for the dancers to move free not only in one spot, but also around the spot according to the specified pattern.

The revitalization in floor patterns is made very interesting. It can be seen when the dancers form an upside-down triangle. Then, the dancers move and see others face to face. They move slanting, forming the $\mathrm{V}$ letter. They form a sequence of straight. It is done to make the dance not monotonous at one spot only. Someone should direct the dancers when they move.

\section{Functions of Daeng Dance}

Initially, the function on Daeng dance was one of the art media to spread Islam. This could be seenfromthe use of tambourine as the instrument that was used in the dance. This dance was also usually performed at religious events. But as time goes by, there has been a shift of function. After a revitalization, this dance is no longer used as the media to spread Islam. It is only used as entertainment only.

\section{Socialization of Daeng Dance}

Daeng dance is socialized through two sets of deployment, a formal socialization that occurs through the authorized institutions under the provisions in the state, such as formal education in the school where the process of revitalization occurs. The second is the informal socialization that takes place in the community or in groups of friends or best friends as well as the mass media.

The socialization of the dance is done through a performance. The dance is usually performed at school events, or events organized by the Department of Tourism in Purbalingga. Those are the right time the dance is experiencing a process of revitalization. Senior High School 1 Bobotsari is a school in which the process of revitalization occurs.

The socialization of Daengdance can be disseminated through a performance and the mass media. It is aimed to let the wider community (areas out of Purbalingga) know the revitalized dance.

\section{CONCLUSION}

Daeng dance is one of the traditional dances. It was once performed by men and 
now it is performed by women. This dance was usually performed in big events, but day after day it began to suffer extinction and was abandoned without any successors. Therefore, Dinbudparpora (Department of Culture, Tourism, and Sports) organizes the revitalization of this dance in Senior High School 1 Bobotsari.

Revitalization is done by means of renovating the form of performance, including motion, accompaniment, makeup, clothing, lighting, staging, and the floor pattern, so that the dance looks more interesting and attractive.

The next process is socialization, through two sorts of deployment, a formal socialization that occurs through the authorized institutions under the provisions in the state, such as formal education in the school where the process of revitalizationoccurs. The second is the informal socialization that takes place in the community or in groups of friends or best friends as well as the mass media.

\section{REFERENCES}

Damanik, F.H.S. (2010). Seribu pena Sosiologi untuk SMA/MA Kelas X. Jakarta: Penerbit Erlangga.

Hadi, S. (2005). Sosiologi Tari. Yogyakarta: Penerbit Pustaka

Hartono. (2000). Seni Tari dalam Persepsi
Masyarakat Jawa. Harmonia Journal of Arts Research and Education. 1(2), 123-130.

Jazuli, M. (1994). Telaah Teoretis Seni Tari. Semarang: IKIP Semarang Press.

Murgiyanto, Sal, M.A. (1983). Pengetahuan Dasar Komposisi Tari. Jakarta: Direktorat Pendidikan Menengah Kejuruan.

Pekerti, Widya. (2008). Metode Perkembangan Seni. Jakarta: Universitas Terbuka.

Ratnaningrum, Ika. (2011). Makna Simbolis dan Peranan Tari Topeng Endel, 11(2), 125-129

Sungkowo, S. (2004). Seni Tari sebagai Muatan Lokal: Sebuah Alternatif. Harmonia, 5(1), 48-54.

Sedyawati, Edi. (1986). Pengetahuan Elmenter Tari Dan Beberapa Masalah Tari. Jakarta: Direktorat Kesenian.

Soedarsono. (1998). Seni Pertunjukan Indonesia di Era Globalisasi. Jakarta: Direktorat Jendral Pendidikan Tinggi Departemen Pendidikan dan Kebudayaan.

Warto. (2014). Revitalisasi Kesenian Kethek Ogleng Untuk Mendukung Pengembangan Pariwisata Di Kabupaten Wonogiri. Paramita, 24 (1), 4762. 